\title{
SHORT-TERM PATTERNS IN THE POST-FIRE DIVERSITY OF LIMESTONE GRASSLANDS AND ROCKY GROUND VEGETATION
}

\author{
MARKoviĆ, S. M. ${ }^{1 *}$-NIKOLIĆ, M. B. ${ }^{2}$-ZLATKOVIĆ, K. B. ${ }^{1}$ - NiKOLIĆ, S. D. ${ }^{1}$ - RAKONJAC, B. Lj. ${ }^{2}-$ \\ STANKOV-JOVANOVIĆ, P. V. ${ }^{1}$ - DJOKIĆ, M. M. ${ }^{1}$ - RATKNIĆ, B. M. ${ }^{2}$ - LuČIĆ, Ž. A. ${ }^{2}$ \\ ${ }^{1}$ Faculty of Science and Mathematics, University of Niš \\ Višegradska 33, P. O. Box 224, 18000 Niš, Serbia \\ (e-mails:marijam@pmf.ni.ac.rs; bojanzlat@yahoo.com;danid@pmf.ni.ac.rs; \\ sjvesna@pmf.ni.ac.rs; mrdjandjokic@gmail.com) \\ ${ }^{2}$ Institute of Forestry, Kneza Višeslava 3, 11030 Belgrade, Serbia \\ (e-mails: smikitis@gmail.com; ljrakonjac@yahoo.com; aleksandar.lucic@gmail.com; \\ mihailoratknic@yahoo.com) \\ *Corresponding author \\ e-mail:marijam@pmf.ni.ac.rs
}

(Received $19^{\text {th }}$ Feb 2018; accepted $18^{\text {th }}$ May 2018)

\begin{abstract}
In the summer of 2007 an enormous wild fire occurred on Vidlič Mt. (Southeast Serbia), which burned down more than 2500 ha of vegetation. Our aim was to study the short-term patterns of diversity changes and vegetation dynamics in the grasslands and rocky ground vegetation affected by the fire. Plots of vegetation were observed according to Braun-Blanquet phytosociological methods. Species richness and Simpson's diversity index were calculated per quadrant for each of three seasons. ANOVA, Unequal HSD post hoc test and Linear Regression were performed in order to follow the post-fire vegetation dynamics and diversity. The species richness and diversity of the fire-affected sites were highest in the zone of thermophilous oak forests, slightly lower in the transitional belt, and lowest in the belt of beech forests. With increasing altitude, the values of richness and diversity decreased. Considering life-forms composition, the most important influence of wildfire was the relationship between two most represented categories, hemicryptophytes and therophytes. It was concluded that the cover values of 13 species show comparatively high levels of statistically significant differences between the stages of vegetation formed in the post-fire period. Limestone grasslands and rocky ground vegetation showed quick recovery after the fire, which indicates that these habitats show comparatively high resilience to fire.
\end{abstract}

Keywords: wildfire, fire-affected, community composition, floristic similarities, burned plots, species richness, life-forms changes, vegetation recovery

\section{Introduction}

Over the last few years, an increasing number of fires have occurred in natural areas. Worldwide, more than 50,000 forest fires occur annually (Aleksić et al., 2009), on average destroying more than 40 million ha of forest (Lukić et al., 2017). There are "fire climate regions" in which fires have a greater frequency and intensity on substrate with good drainage, and this, combined with the flammability of the dead combustible materials results in any fire having a greater surface area (Dimitrov, 1999). Jurjević et al. (2007) point out that there are three areas that are seriously endangered by fires on Earth: the Mediterranean, the North American area of pine forests and the area of African savannas because of their climate, weather conditions and the character of the substrate. In Europe alone 30,000-40,000 forest fires a year take place and the fireaffected area amounts to over 500,000 ha annually (Jurjević et al., 2007). Damage in 
North America is significantly higher. In Europe, most fires take place in the in ecosystems of the Mediterranean: Italy, France, Greece, Spain, Portugal and Croatia (Margaletić and Margaletić, 2003; Türkmen and Düzenli, 2011). In humid regions there are not as many forest fires and the consequences are not nearly as disastrous (Vukelić and Rauš, 1998).

Between 2004 and 2013, 3800 ha (2250 ha categorized as forests) were destroyed by fire in Serbia (Nikolov, 2015). In just five years (2003-2007) 580 fires were counted and most of them (64\%) were in 2007 (Tabaković-Tošić et al., 2009).

The comparative fire ecology of plant communities on serpentinite and sandstone substrates, especially the degree to which species diversity depends on fire, has been underlined by Safford and Harrison (2004). In addition, Pausas and Ribeiro (2017) provided insights into several positive effects of fire on grasslands formed on rocky areas, emphasizing its role in increasing the landscape variability, creating new ecological niches, thereby ensuring the improvement of general plant diversity.

Although several studies on the effects of fire on vegetation in Serbia and its surroundings have been reported (Čolić, 1960, 1966; Vukićević, 1965; Dinić et al., 2003; Janković, 2003; Marković et al., 2015a, 2016), only a few of them consider longterm post fire regeneration patterns in forests focusing on species richness and diversity (Vukićević, 1965; Čolić, 1966). The short-term patterns of dry grasslands and rocky outcrop vegetation over the limestone formations have not yet been investigated in the central Balkans. Furthermore, no studies have yet evaluated the effects of fire on grasslands growing over limestone derived soils, which is one of the most highly represented types of vegetation in the mountain regions of the northeastern, eastern and southeastern parts of Serbia. The carbonate substrate predominant on Vidlič Mountain contributes to the faster and greater warming and drying of terrestrial vegetation (Margaletić and Margaletić, 2003) and it is more sensitive to the occurrence of fire.

The wildfire on Vidlič Mountain happened in 2007 and burned over 2500 ha of grasslands, shrubbery and forest vegetation, considerably changing the landscape of the mountain (Ministry of the Environment and Spatial Planing, 2008), and a forest area of 1000 ha was impacted by uncontrolled wildfire (Panić, 2007). Subsequently, a large area of open grassy and dwarf shrubbery semi-opened vegetation of approximately 1000-1500 ha was also engulfed by fire. The wildfire crossed the skeletal slopes rapidly. The repercussions of the fire on these habitats were neither recorded nor repaired by any governmental organization, as they were in the case of forests, whereby the State Forestry Enterprise was fully engaged.

Several fundamental studies of xeric vegetation in Serbia have already been performed by Jovanović-Dunjić (1955, 1956), Danon (1960), Diklić (1962), Diklić and Nikolić (1964). This vegetation plays an important role in stopping further denudation in limestone areas. During the previous century, a well-developed area of forest on Vidlič Mountain was largely destroyed, remaining mainly on the northern and eastern slopes. Deciduous forest of Hungarian and Turkish oak (Quercetum frainetto-cerris Rudski 1949), one of the most widespread types of forest is considered to be climax in the region (Mišić et al., 1978). Different stages of degradation of this community are present on the mountain. The fragments with oriental hornbeam (Carpinus orientalis) are one of them. The upper region of the mountain is covered by moesian beech forests (Fagetum montanum moesiacum), considered to be a climate-regional community. After woodcutting, and the period of subsequent grazing, many types of meadows, xeric pastures and shrub-like vegetation native to rocky slopes were formed over the vast area 
of eroded slopes. Thus, xeric vegetation in the region is secondary by origin, representing the plagioclimax in the habitat of well-developed deciduous woodland. Its origin, floristic composition and structure are also determined by the warm climate, and particularly by edaphic factors (Diklić and Nikolić, 1964). Bearing steppe characteristics, which is indicated by presence of numerous sub-Mediterranean species, this vegetation is important for many reasons. It plays an important role in stopping further denudation not only regionally, but also in the wider limestone areas of the Peninsula. Different varieties of xeric pastures are traditionally used for grazing, which was particularly popular in previous centuries. This vegetation is also important as a source of medicinal (Marković et al., 2010) and especially aromatic plants (Marković et al., 2009). Finally, in spite of the barren and shallow soils, the xeric vegetation of this region is rich in plant species, especially endemic, endangered and steppe relict representatives (e.g. Adonis vernalis, Paeonia tenuifolia, Ranunculus illyricus, Sternbergia colchiciflora, Hyacinthella leucophaea).

Our general hypothesis was that the effects of wildfire on plant communities and their diversity would be weaker on more fertile limestone soils and soils with frequent rocky outcrops. We assumed that well represented rocky fraction, typical for the limestone areas, could play an important role in following phenomena:

1) Limestone soils have higher ratios of herbaceous to woody fuels, thus increasing fire spread rates, decreasing fire intensity, and reducing soil heating - fire move faster, and therefore, its impact could be less severe.

2) Soil layer could be only shallowly affected, so the seed bank in the ground would be better preserved.

3) Limestone soils have frequent rocky outcrops which can provide safe sites for plants to avoid burning, saving unburned "patches" of initial vegetation.

The short-term patterns of post-fire diversity for the open and semi-opened, herbaceous to shrubby vegetation on the Vidlič Mt. calcareous plateau in the central Balkan Peninsula were chosen as the object of the present study. To the best of our knowledge, this is the first significant contribution to the post-fire ecology of limestone areas across the Peninsula.

\section{Material and methods}

\section{Study area}

The study was conducted in fire-affected areas of Vidlič Mt., including surfaces covered by dry grasslands and rocky ground vegetation (Fig. 1). Vidlič Mt. is an extension of the Stara Planina (Balkan Mt.) mountain chain, which is a large calcareous plateau located in eastern Serbia (Vidanović, 1955). Its ridge stretches in a prevailing northwest-southeast direction between Serbia and Bulgaria (Petrović, 1999). In geological terms the mountain is mostly built of limestone and dolomite formations, with well-represented cretaceous, jurassic and triassic layers (Vidanović, 1960; Petrović, 1999). Smaller areas are covered with marlstone and sandstone (Andjelković, 1977). Dry skeletal and barren land covers the mighty rocky deposits over the whole area. The prevailing soil types are rendzina and calcomelanosol, which achieve different evolutionary forming phases (Antonović and Mrvić, 2008). Rendzina is nutrient-poor soil formed on soft limestone, as well as on carbonate and silicate substrates like marlstone and sandstone. Calcomelanosol is shallow, humus rich soil formed on limestone and dolomite containing a high percentage of calcium and magnesium 
carbonate (Miljković, 1996). The climate is temperate continental, with hot summers and prominent drought periods. Climate steppe and mediterranean influences are represented across the large base, while the upper part of the mountain has features of a mountain climate (Vidanović, 1960). The mountain is characterized by dynamic relief, inclined slopes, and vast deforested areas exposed to extensive erosion.

The main focus in our previous study (Marković et al., 2015b) was on grasslands belonging to the already familiar alliances Festucion valesiacae (Festuco-Brometea) and Seslerion rigidae (Festuco-Seslerietea). Carici humilis-Stipetum pulcherrimae, Potentillo-Caricetum humilis and Sanguisorbo-Festucetum vallesiacae are the most commonly represented associations in the investigated area. Great attention was also dedicated to the fire-affected vegetation of extremely eroded areas, in particular Euphorbio myrsiniti-Bothriochloetum (Chrysopogoni-Satureion), that represents final degradation stage of termophilous forests, as one of the most common associations on rocky ground.

In our previous study we investigated the vegetation of 10 unburned plots on Vidlič Mt. in detail (Marković et al., 2015b). The phytocoenoses investigated from unburned areas were found to be similar to those that cover other limestone areas in this region. In the present study, unburned areas were compared with burned ones.

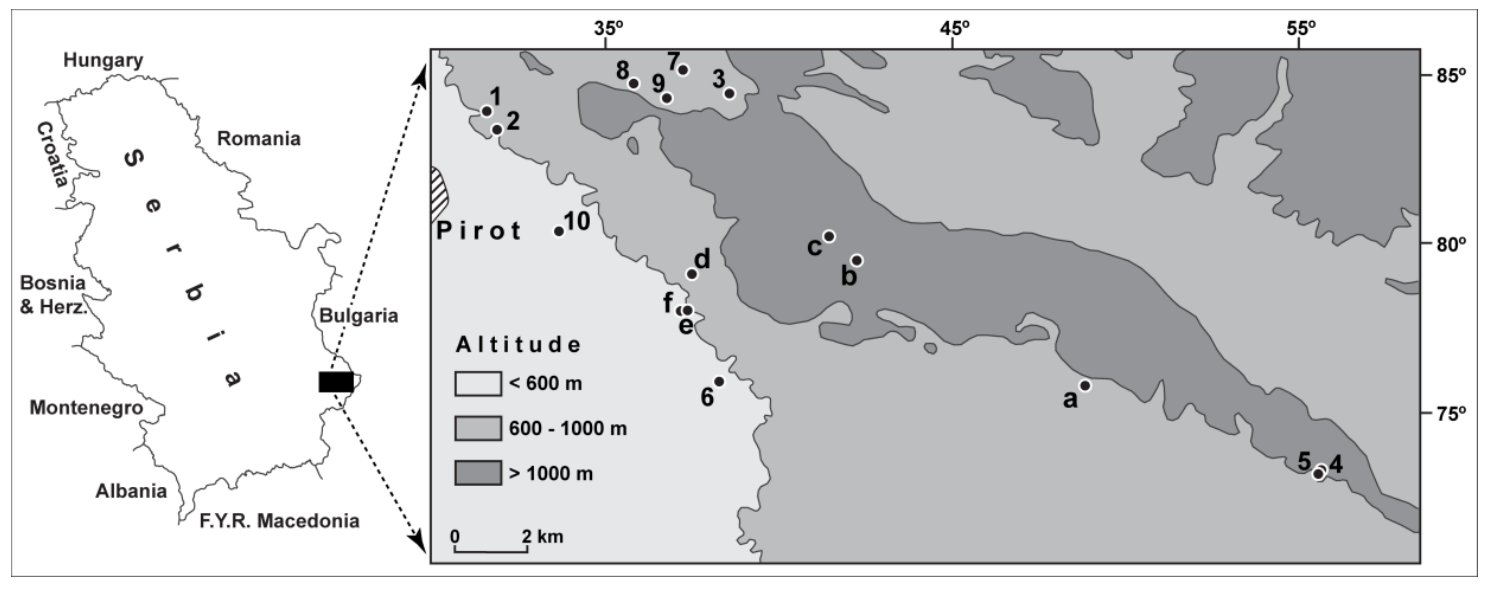

Figure 1. The area of Vidlič Mt. investigated and location of the plots analyzed: the spatial position of the plots referring to fire non-affected vegetation (1-10) and plots referring to the vegetation of fire-affected localities (a-f). (1,2 - Mali Vrh; 3 - Basara; 4, 5 - Vlkovija; 6 Vučje; 7, 8, 9 -Crni vrh;10-Izvor; a -Visočki Odorovci; b, c-Basarski kamik; d, e,fVučje)

\section{Data collection procedures}

The vegetation dynamic of burned xeric grasslands in three consecutive seasons (2008-2010) was followed, and a comparison between the stages of vegetation established at the burned sites with the vegetation of similar, unburned habitats was carried out. In order to track changes in the vegetation at the burned and unburned plots, six phytocoenological plots (a-f) were made in the first, second and third years after the fire. Plots from unburned areas were chosen randomly, and plots from burned areas were then taken from the same vegetational belt. In the beech forests belt unburned plots for comparison were found at greater distances from the burned plots (Fig. 1). Plot data for the fire non-affected vegetation as well as for fire affected vegetation are 
presented in Table 1. The position of every plot was georeferenced using Ozi explorer and displayed on the map (Fig. 1) using DIVA-GIS (5.2) software (Hijmans et al., 2005).

Table 1. Plot data for the fire non-affected (1-10) and fire-affected vegetation (a-f) at Vidlič Mt. Plots 1-10 represent unburned areas, which was the subject of the investigation in our previous study (Marković et al., 2015b)

\begin{tabular}{|c|c|c|c|c|c|c|c|}
\hline Plot & Locality & $\begin{array}{c}\text { Latitude } \\
\text { [N] }\end{array}$ & $\begin{array}{c}\text { Longitude } \\
{[E]}\end{array}$ & \begin{tabular}{|c|} 
Altitude \\
{$[\mathrm{m}]$}
\end{tabular} & $\begin{array}{c}\text { Vegetation } \\
\text { belt }\end{array}$ & Exposure & \begin{tabular}{|c|}
$\begin{array}{c}\text { Terrain } \\
\text { inclination }\left[{ }^{\circ}\right]\end{array}$ \\
\end{tabular} \\
\hline 1 & Mali vrh & $43^{\circ} 10^{\prime} 53^{\prime \prime}$ & $22^{\circ} 37^{\prime} 15^{\prime \prime}$ & 635 & Oak forests & $\mathrm{W}$ & 20 \\
\hline 2 & Mali vrh & $43^{\circ} 10^{\prime} 37^{\prime}$ & $22^{\circ} 37^{\prime} 26^{\prime \prime}$ & 620 & Oak forests & $S$ & 5 \\
\hline 3 & Basara & $43^{\circ} 11^{\prime} 04^{\prime \prime}$ & $22^{\circ} 42^{\prime} 03^{\prime}$ & 900 & Transitional & SW & 10 \\
\hline 4 & Vlkovija & $43^{\circ} 05^{\prime} 24^{\prime \prime}$ & $22^{\circ} 53^{\prime} 35^{\prime \prime}$ & 1100 & Beech forests & S & 40 \\
\hline 5 & Vlkovija & $43^{\circ} 05^{\prime} 23^{\prime \prime}$ & $22^{\circ} 53^{\prime} 34^{\prime \prime}$ & 1090 & Beech forests & S & 30 \\
\hline 6 & Vučje & $43^{\circ} 06^{\prime} 54^{\prime \prime}$ & $22^{\circ} 41^{\prime} 44^{\prime \prime}$ & 490 & Oak forests & $\mathrm{W}$ & 15 \\
\hline 7 & Crni vrh & $43^{\circ} 11^{\prime} 25^{\prime \prime}$ & $22^{\circ} 41^{\prime} 08^{\prime \prime}$ & 810 & Transitional & S & 5 \\
\hline 8 & Crni vrh & $43^{\circ} 11^{\prime} 14^{\prime \prime}$ & $22^{\circ} 40^{\prime} 10^{\prime}$ & 930 & Transitional & S & 35 \\
\hline 9 & Crni vrh & $43^{\circ} 11^{\prime} 01^{\prime \prime}$ & $22^{\circ} 40^{\prime} 48^{\prime \prime}$ & 890 & Transitional & S & 15 \\
\hline 10 & Izvor & $43^{\circ} 09^{\prime} 07^{\prime}$ & $22^{\circ} 38^{\prime} 37^{\prime}$ & 480 & Oak forests & $\mathrm{W}$ & 40 \\
\hline $\mathrm{a}$ & Visočki Odorovci & $43^{\circ} 06^{\prime} 44^{\prime}$ & $22^{\circ} 48^{\prime} 58^{\prime \prime}$ & 900 & Transitional & S & 35 \\
\hline $\mathrm{b}$ & Basarski kamik & $43^{\circ} 08^{\prime} 36^{\prime \prime}$ & $22^{\circ} 44^{\prime} 30^{\prime \prime}$ & 1100 & Beech forests & $\mathrm{E}$ & 35 \\
\hline $\mathrm{c}$ & Basarski kamik & $43^{\circ} 08^{\prime} 58^{\prime \prime}$ & $22^{\circ} 43^{\prime} 58^{\prime \prime}$ & 1150 & Beech forests & E & 10 \\
\hline $\mathrm{d}$ & Vučje & $43^{\circ} 08^{\prime} 28^{\prime \prime}$ & $22^{\circ} 41^{\prime} 14^{\prime \prime}$ & 710 & Transitional & S & 10 \\
\hline $\mathrm{e}$ & Vučje & $43^{\circ} 07^{\prime} 56^{\prime \prime}$ & $22^{\circ} 41^{\prime} 08^{\prime \prime}$ & 558 & Oak forests & $S$ & 30 \\
\hline $\mathrm{f}$ & Vučje & $43^{\circ} 07^{\prime} 55^{\prime}$ & $22^{\circ} 41^{\prime} 03^{\prime \prime}$ & 524 & Oak forests & SW & 25 \\
\hline
\end{tabular}

The Braun-Blanquet method (1964) was applied for phytocoenological analysis. The 10 plots per fire affected site (quadrants $100 \mathrm{~m}^{2}$ ) were analysed. Phytocoenological analysis included data on the locality, altitude, exposure, terrain inclination, plot area, abundance, cover, plot code, floristic composition and degree of presence. The plant material collected was identified according to Josifović (1970-1977) and Velchev (1982-1989) and the nomenclature was adjusted according to Tutin et al. (1964-1980, 1993). The plant material was collected during the summers of 2008-2010 (June, July and August) and deposited in the "Herbarium Moesiacum Niš", University of Niš (HMN).

\section{Data analysis}

The combined values were transformed into a numerical scale as proposed by Westhoff and Van der Maarel (1973) to enable comparison of the floristic composition of the plots in different seasons. Simpson's diversity of species in the community, within the minimum range, was performed in the Flora software package (Karadžić et al., 1998). The species richness (the total number of species), and Simpson's diversity index (Whitaker, 1972) that includes species evenness, were calculated per quadrant $\left(100 \mathrm{~m}^{2}\right)$ for each of three seasons. The mean values of richness and diversity for the plots were presented. 
Descriptive statistics (Means, Standard Deviations) of richness and diversity were calculated. The influence of fire damage and elevation on the values of richness and diversity were tested using one way and two way analysis of variance (ANOVA) and the $95 \%$ LSD test was used to analyze the differences between the fire-affected and non-affected plots and different altitudes. Linear regression was performed in order to estimate the correlations between the richness/diversity and altitude, exposure and slope. The analysis of variance (ANOVA) was also used to determine whether there were differences in the floristic composition of the main stages of vegetation in the post-fire period. The unequal HSD post-hoc procedure was used to identify the exact seasons (I-III) that show differences in the mean values of significant species. The univariate analysis of species cover values was performed on taxa with highest presence in the plots $(60-80 \%$ and $80-100 \%)$ per year, resulting in the descriptive statistics presented in Table 4. All of the statistical analyses quoted here were performed using the STATGRAPHICS Plus 5.0 software.

A comparison of the floristic similarities between the burned and unburned plots in the second and third year were made using Sorensen's coefficient of similarity (Sc) based on presence vs. absence (Smith and Killeen, 1995).

The system proposed by Mueller-Dombois and Ellenberg (1974) modified by Stevanovic (1992) is used for the identification of plant life-forms as follows: phanerophytes $(\mathrm{P})$, chamaephytes $(\mathrm{Ch})$, hemicryptophytes $(\mathrm{H})$, geophytes $(\mathrm{G})$ and therophytes (T). In order to find out how the life-form composition changed, the percent of the basic groups was observed during the first, second and third year of post-fire period and compared with the components of fire non-affected vegetation.

\section{Results}

\section{Species richness and diversity}

In the first year after the fire (Fig. 2A, B) the species richness and diversity of the fire-affected sites was the highest in plots e and $\mathrm{f}$, located in the zone of degraded thermophilous oak forests (Quercetum frainetto-cerris subass. carpinetosum orientalis) formed at low altitudes $(500-600 \mathrm{~m})$ (Fig. 3A, B). Slightly lower richness and diversity were noted in localities (a and d) from the transitional belt between the oak (Quercetum montanum) and beech forests at upper altitudes $(700-900 \mathrm{~m})$. On the plots (b and c) located in the belt of beech forests (Fagetum moesiacae montanum) over $1000 \mathrm{~m}$ above sea level, the poorest values of richness and diversity were recorded. As expected, in the second and third year after the fire (2009 and 2010) an increasing trend of richness and diversity was registered in almost all plots (Fig. 2A, B).

By calculating the average values of diversity, it was noticed that the richness and diversity of the burned vegetation were generally reduced in comparison to the unburned areas (Fig. 4A, B). After an initial fall, richness and diversity generally had an increasing trend, but did not reach the values of unburned vegetation in the third year (Table 2). However, over time, richness (expressed as extreme range and standard deviation values) exerted an upward trend, while for diversity the opposite was true. Fire damage and elevation caused statistically significant differences in both richness and diversity but no interaction between them was found (Two-way ANOVA) (Table 3). Furthermore, differences between burned (a-f) and unburned areas (1-10) as well as differences between altitude belts (up to $600 \mathrm{~m}, 600-1000 \mathrm{~m}$ and over $1000 \mathrm{~m}$ ) 
were also confirmed (homogenous groups - A and B, obtained by LSD tests, denoted differences in $95 \%$ of the cases) (Table 2).

A

Box-and-Whisker Plot

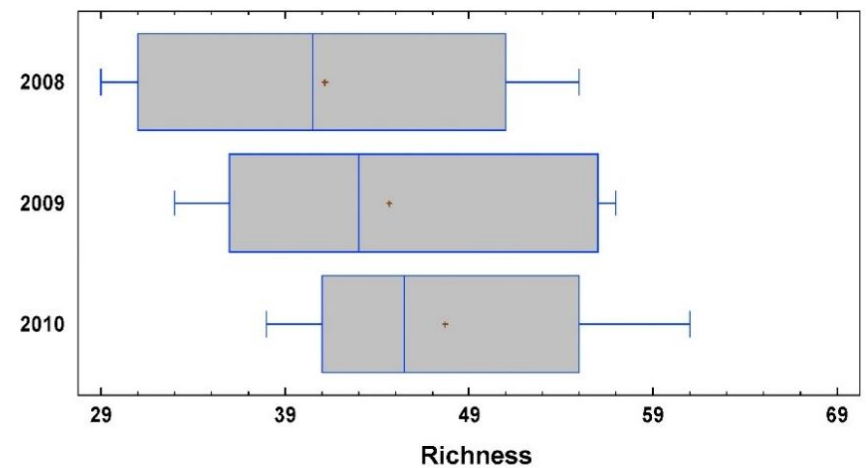

B

Box-and-Whisker Plot

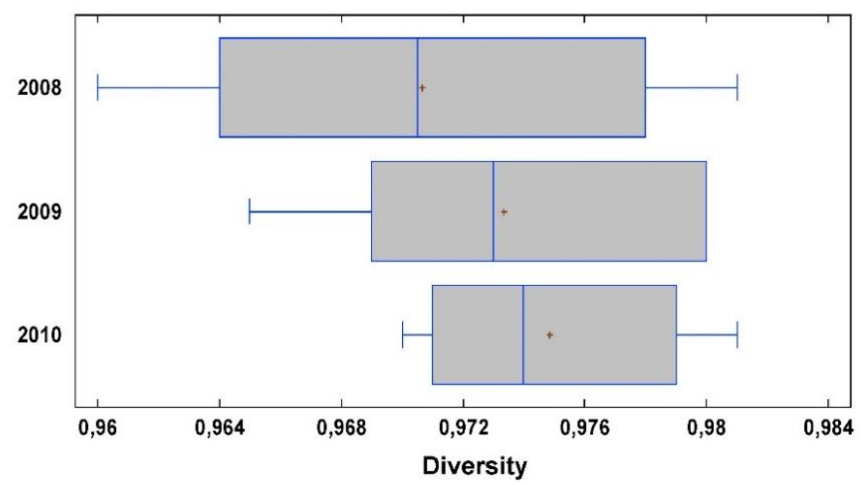

Figure 2. Species richness (total number of species) (A) and diversity (Simpson's index) (B) of the plots in three consecutive years

Table 2. Differences between plots in terms of richness (total number of species) and diversity (Simpson's index). All F-ratios are based on the residual mean square error

\begin{tabular}{c|c|c|c|c|c|c|c}
\hline \multirow{2}{*}{ Source } & \multirow{2}{*}{ Count } & \multicolumn{3}{|c|}{ Richness } & \multicolumn{3}{c}{ Diversity } \\
\cline { 3 - 8 } & & Range & Mean value & SD & Range & Mean value & SD \\
\hline FACTOR: FIRE DAMAGE \\
\hline a-f (2008) & 6 & $29-55$ & $40.33^{\mathrm{A}}$ & 11.18 & $0.960-0.981$ & $0.970^{\mathrm{A}}$ & 0.01 \\
a-f (2009) & 6 & $33-57$ & $44.67^{\mathrm{A}}$ & 10.46 & $0.965-0.980$ & $0.973^{\mathrm{A}}$ & 0.01 \\
a-f (2010) & 6 & $38-61$ & $47.67^{\mathrm{A}}$ & 8.76 & $0.970-0.981$ & $0.975^{\mathrm{A}}$ & 0.00 \\
1-10 (2008) & 10 & $46-76$ & $5768^{\mathrm{B}}$ & 9.54 & $0.976-0.985$ & $0.980^{\mathrm{B}}$ & 0.00 \\
\hline
\end{tabular}

Different letters (A and B) indicate significant difference at $\mathrm{P} \leq 0.001$ among the cases 
Table 3. Two-way analysis for richness and diversity - Type III Sums of Squares. Factors: fire damage and elevation. All F-ratios are based on the residual mean square error

\begin{tabular}{c|c|c|c|c|c}
\hline \multirow{2}{*}{ Source } & \multirow{2}{*}{ df } & \multicolumn{2}{|c|}{ Richness } & \multicolumn{2}{c}{ Diversity } \\
\cline { 3 - 6 } & & F-ratio & P-value & F-ratio & P-value \\
\hline MAIN EFFECTS & & & & & \\
Fire damage & 1 & 13.78 & 0.0011 & 15.05 & 0.0007 \\
Elevation (m) & 2 & 4.67 & 0.0193 & 7.43 & 0.0031 \\
RESIDUAL & 24 & & & & \\
TOTAL (CORRECTED) & 27 & & & & \\
\hline
\end{tabular}

A

Box-and-Whisker Plot

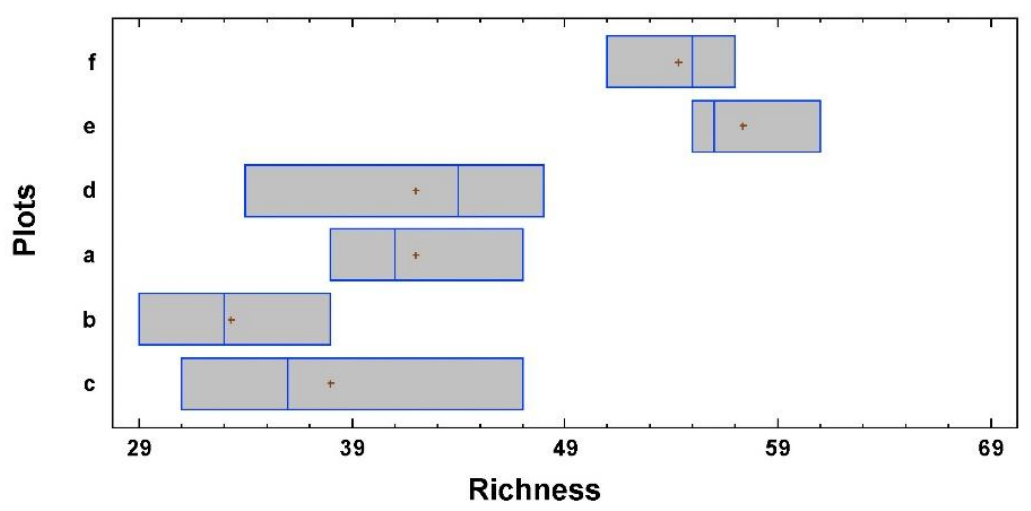

Box-and-Whisker Plot

B

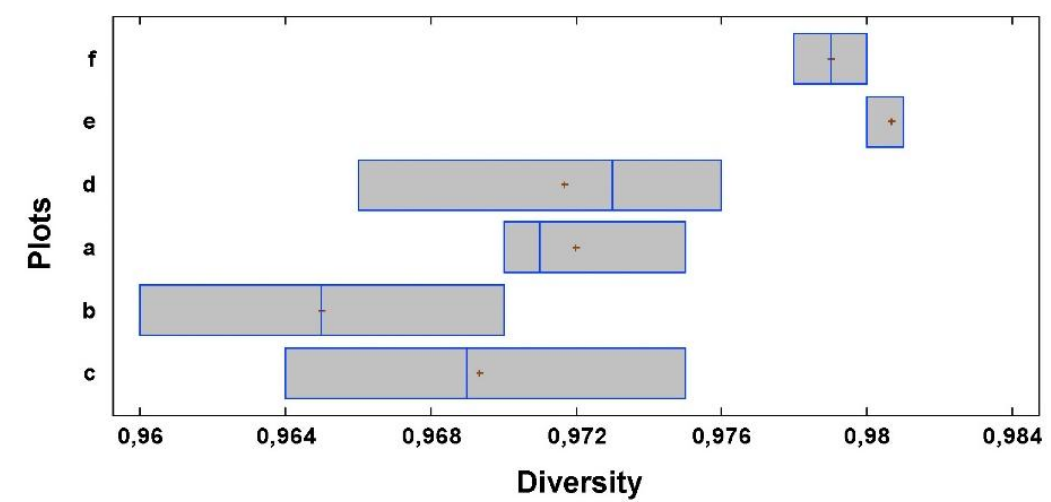

Figure 3. Mean values of species richness (total number of species) (A) and diversity (Simpson's index) (B) per plots

\section{Correlations with environmental variables}

Richness and diversity had a strong positive correlation $(\mathrm{r}=0.98$; ANOVA $p$ value $=0.0001$ ) (see also Fig. 3A, B). With increasing altitude, the values of richness and diversity decreased $(\mathrm{r}=-0.80$ and -0.78 , resp.; $p$-values $=0.0001)$. But richness and 
diversity increased towards E-WS showing moderate positive correlations ( $\mathrm{r}=0.69$ and 0.68 , resp.; $p$-values $=0.0001)$. The correlation between diversity and richness and the slope of the terrain were weak and without statistically significant differences $(r=0.10$ and 0.05, resp.; ANOVA $p$-values $>0.01$ ). But richness and diversity have significant strong negative correlations with the vegetation belt (from oak, through transitional to beech forest $)(\mathrm{r}=-0.85$ and -0.85 , resp.; $p$-values $=0.0001)$.

A

Box-and-Whisker Plot

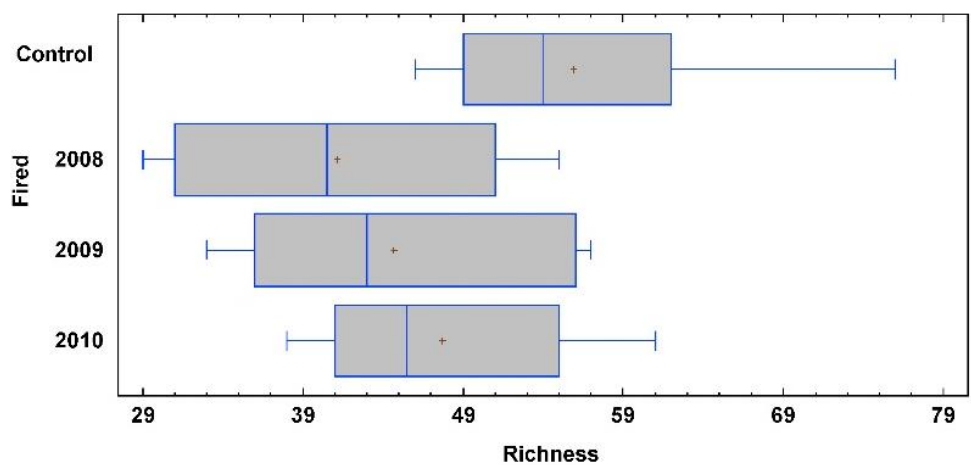

B

Box-and-Whisker Plot

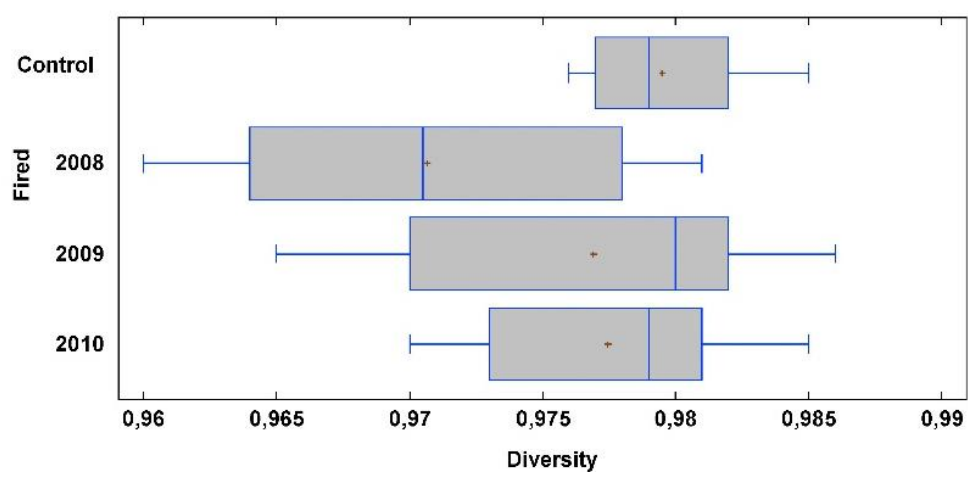

Figure 4. Mean values of richness and diversity of fire non-affected plots (control) and fireaffected plots in three consecutive years

\section{Life-forms dynamics in post-fire period}

The life-form composition of the vegetation of fire non-affected plots (1-10) could be described by the dominance of herbs $(\mathrm{H})$, including forbs and grasses, represented with $54 \%$, but also large percent of annual plants $(\mathrm{T})$, represented with $32 \%$ of all registered species. The group of generally low plants, with semifruticose sprouts $(\mathrm{Ch})$ was presented with $7 \%$ in this vegetation. The plants that survived thanks to solid subterranean organs $(\mathrm{G})$ were represented with $5 \%$, while the percent of shrub species (P) was approximately $2 \%$. The composition of life-forms in the vegetation of fireaffected plots (a-i) is considerably different due to the fire influence and became unstable, especially in the first period of post fire recovery. The most important consequence of wildfire is the relationship between two best represented growth-form 
categories, hemicryptophytes and therophytes. The percent of annual representatives in the vegetation of the fire-affected plots (a-i) rapidly increased in the first stage of its revitalization. Under the new conditions, the presence of therophytes (44\%) almost exceeds percentages of herbaceous perennial plants, represented with $46 \%$ in the first year. Other functional groups, chamaephytes (8\%), geophytes $(7 \%)$ and phanerophytes $(1 \%)$ were lesser represented in that phase. In the second year of post-fire period, the proportion of therophytes gradually decreased compared to hemicryptophytes (36\% vs. $47 \%$ ) while percentage of chamaephytes $(11 \%)$ began to be more significant. As expected, during the third year of observation, the percent of hemicryptophytes increased $(49 \%)$ while of therophytes decreased to $32 \%$. The contribution of other vegetation components in the final year of observation was as follows: chamaephytes $12 \%$, geophytes $5 \%$ and phanerophytes $2 \%$. Considering life-form of taxa with higher phytocoenological importance, a significant role could be assigned to perennial grass species Festuca valesiaca that was dominant in vegetation of all studied post-fire stages. However, significant abundance and coverage were also achieved by some annual species, e.g. Bromus squarrosus, Filago montana (firs year) and Sideritis montana (first and second year), which easily inhabited burned plots in the initial stages. During the middle post-fire period the vegetation was characterized by higher cover values of $F$. valesiaca and perennial species Teucrium chamaedrys, as well as comparatively low cover values of annual species. Increasing cover values of other herbaceous perennial plants beside F. valesiaca (e.g. Euphorbia cyparissias, Medicago falcata and Galium purpureum), along with almost insignificant coverage of therophytes, which was recorded in the final year of observation.

\section{Univariate analysis of species cover values in relation to vegetation dynamics}

According to the results of the ANOVA test it was concluded that the values of 13 out of the 21 species compared possess comparatively high levels of statistically significant differences between groups of taxa based on their phytocoenological importance in the post-fire period (Table 4). The following species stand out because of their high F values: 1) Centaurea stoebe and 2) Sanguisorba minor. These species can have an extremely significant role in floristic as well as phytocoenological differentiation between the stages in the early post-fire period of restoration. Among the other species, Bromus squarrosus, Filago montana, Hieracium bauhinii, Rosa canina, Koeleria splendens, Eryngium campestre, Medicago falcata and Fragaria vesca could also play an important role in the post-fire dynamics of the vegetation.

The unequal HSD post hoc test confirmed that all 13 species represent important indicators of post-fire dynamics in calcareous grassland and bedrock vegetation. There were especially significant differences in the cover values of $C$. stoebe, $S$. minor and $R$. canina in the third year, while B. squarrosus and $F$. montana were more represented during the first year after the fire (Table 4).

\section{Floristic similarity between the unburned and burned vegetation}

The floristic similarity between the unburned and burned vegetation in the first three years after the fire was lower than 50\% according to Sorensen's coefficient of similarity. The unburned and burned plots in the oak forest belt at lower altitudes showed the highest values (Table 5). The lowest similarity was recorded between the unburned and burned plots in the beech forest belt at higher altitudes (20-27\%). 
Table 4. Results of the univariate analysis of species cover values during the post fire period

\begin{tabular}{|c|c|c|c|c|c|}
\hline Taxon & $\mathbf{F}^{1}$ & $\mathbf{P}^{2}$ & $\mathbf{I}^{3}$ & II & III \\
\hline Asperula cynanchica $^{\mathrm{H}}$ & 1.97 & & $2.17 \pm 0.41$ & $2.33 \pm 0.52$ & $1.67 \pm 0.82$ \\
\hline Bromus squarrosus $^{\mathrm{T}}$ & 10 & $* *$ & $1.33 \pm 1.03^{\mathrm{a}}$ & $0.00^{\mathrm{b}}$ & $0.00^{\mathrm{b}}$ \\
\hline Centaurea stoebe ${ }^{\mathrm{H}}$ & 25 & $* * *$ & $0.00^{\mathrm{a}}$ & $0.00^{\mathrm{a}}$ & $1.67 \pm 0.82^{\mathrm{b}}$ \\
\hline Crataegus monogyna $^{\mathrm{P}}$ & 0.28 & & $1.33 \pm 1.03$ & $1.67 \pm 0.82$ & $1.67 \pm 0.82$ \\
\hline Eryngium campestre ${ }^{\mathrm{H}}$ & 8.08 & $* *$ & $0.00^{\mathrm{a}}$ & $1.67 \pm 0.82^{\mathrm{b}}$ & $1.33 \pm 1.03^{\mathrm{b}}$ \\
\hline Euphorbia cyparissias $^{\mathrm{H}}$ & 1.65 & & $1.50 \pm 1.22$ & $1.83 \pm 0.98$ & $2.67 \pm 1.21$ \\
\hline Festuca valesiaca $^{\mathrm{H}}$ & 0.12 & & $3.33 \pm 2.07$ & $2.67 \pm 2.80$ & $2.83 \pm 2.48$ \\
\hline Filago montana $^{\mathrm{T}}$ & 10 & $* *$ & $1.33 \pm 1.03^{\mathrm{a}}$ & $0.00^{\mathrm{b}}$ & $0.00^{\mathrm{b}}$ \\
\hline Fragaria vesca $^{\mathrm{H}}$ & 5 & * & $0.00^{\mathrm{a}}$ & $1.33 \pm 1.03^{\mathrm{b}}$ & $1.33 \pm 1.03^{\mathrm{b}}$ \\
\hline Galium purpureum ${ }^{\mathrm{H}}$ & 0.02 & & $2.00 \pm 1.10$ & $2.17 \pm 1.94$ & $2.17 \pm 1.94$ \\
\hline Hieracium bauhinii $^{\mathrm{H}}$ & 10 & $* *$ & $0.00^{\mathrm{a}}$ & $0.00^{\mathrm{a}}$ & $1.33 \pm 1.03^{\mathrm{b}}$ \\
\hline Koeleria splendens ${ }^{\mathrm{H}}$ & 9 & $* *$ & $0.00^{\mathrm{a}}$ & $0.00^{\mathrm{a}}$ & $1.50 \pm 1.22^{\mathrm{b}}$ \\
\hline Medicago falcata ${ }^{\mathrm{H}}$ & 6.94 & $* *$ & $0.00^{\mathrm{a}}$ & $2.50 \pm 1.64^{\mathrm{b}}$ & $2.50 \pm 1.64^{\mathrm{b}}$ \\
\hline Medicago lupulina ${ }^{\mathrm{H}}$ & 5.99 & * & $0.00^{\mathrm{a}}$ & $0.00^{\mathrm{a}}$ & $1.83 \pm 1.83^{\mathrm{b}}$ \\
\hline Petrorhagia saxifraga ${ }^{\mathrm{H}}$ & 0 & & $1.67 \pm 0.82$ & $1.67 \pm 0.82$ & $1.67 \pm 0.82$ \\
\hline Rosa canina $^{\mathrm{P}}$ & 10 & $* *$ & $0.00^{\mathrm{a}}$ & $0.00^{\mathrm{a}}$ & $1.33 \pm 1.03^{\mathrm{b}}$ \\
\hline Sanguisorba minor ${ }^{\mathrm{H}}$ & 25 & $* * *$ & $0.00^{\mathrm{a}}$ & $0.00^{\mathrm{a}}$ & $1.67 \pm 0.82^{\mathrm{b}}$ \\
\hline Satureja kitaibelii ${ }^{\mathrm{Ch}}$ & 0.02 & & $2.17 \pm 1.94$ & $2.00 \pm 1.90$ & $2.00 \pm 1.90$ \\
\hline Sideritis montana $^{\mathrm{T}}$ & 3.87 & * & $3.17 \pm 3.19^{\mathrm{a}}$ & $1.50 \pm 1.22^{\mathrm{ab}}$ & $0.00^{\mathrm{b}}$ \\
\hline Teucrium chamaedrys ${ }^{\mathrm{H}}$ & 1.57 & & $1.67 \pm 1.37$ & $3.00 \pm 1.10$ & $3.33 \pm 2.42$ \\
\hline Teucrium montanum ${ }^{\mathrm{H}}$ & 5 & * & $0.00^{\mathrm{a}}$ & $1.33 \pm 1.03^{\mathrm{b}}$ & $1.33 \pm 1.03^{\mathrm{b}}$ \\
\hline
\end{tabular}

${ }^{1} \mathrm{~F}$ : ANOVA F-test

${ }^{2} \mathrm{P}$ : Level of significance $(*: \mathrm{P}<0.05 ; * * \mathrm{P}<0.01$; ***: $\mathrm{P}<0.001)$

${ }^{3}$ Cover values (mean \pm standard deviation) according to Van der Maarel (1966); means with different superscript letters within the same row differ significantly (Unequal HSD post-hoc test)

Life-forms: ${ }^{\mathrm{Ch}}$ ) chamaephytes, ${ }^{\mathrm{H}}$ ) hemicryptophytes, ${ }^{\mathrm{P}}$ ) phanerophytes, $\left.{ }^{\mathrm{T}}\right)$ therophytes

Table 5. Floristic similarity between fire non-affected and fire-affected vegetation in the first, second and third year after burning summed up to the vegetation belts. Total number of species found in fire non-affected (A) and fire-affected vegetation (B), number of species in common between non-affected and fire-affected vegetation (C), Sorensen's coefficient of similarity based on presence vs. absence - Sc (\%)

\begin{tabular}{c|c|c|c|c}
\hline \multirow{2}{*}{ Vegetation belt } & \multicolumn{2}{|c|}{ Total number of species } & \multicolumn{2}{c}{ Floristic similarity } \\
\cline { 2 - 5 } & A & B & $\mathbf{C}$ & $\mathbf{S}_{\mathbf{c}}(\boldsymbol{\%})$ \\
\hline Oak forests $<600 \mathrm{~m}$ & 120 & 80 & 45 & 45 \\
\hline Transitional belt $600 \mathrm{~m}-1000 \mathrm{~m}$ & 138 & 65 & 41 & 40 \\
Beech forests $>1000 \mathrm{~m}$ & 113 & 47 & 16 & 20 \\
\hline \multicolumn{5}{|c|}{$2009\left(2^{\text {nd }}\right.$ year $)$} \\
\hline Oak forests $<600 \mathrm{~m}$ & 120 & 91 & 52 & 49 \\
Transitional belt $600 \mathrm{~m}-1000 \mathrm{~m}$ & 138 & 71 & 45 & 43 \\
Beech forests $>1000 \mathrm{~m}$ & 113 & 52 & 20 & 24 \\
\hline & 120 & 90 & 46 & 44 \\
\hline Oak forests $<600 \mathrm{~m}$ & 138 & 72 & 46 & 44 \\
Transitional belt $600 \mathrm{~m}-1000 \mathrm{~m}$ & 113 & 62 & 24 & 27 \\
Beech forests $>1000 \mathrm{~m}$ & \multicolumn{5}{|c}{} \\
\hline
\end{tabular}




\section{Discussion}

The specific patterns of succession of calcareous grasslands in different conditions and regions in Europe have been the subject of several recent studies (Alard et al., 2005; Schrautzer et al., 2009). Rutherford et al. (2011) have studied post-fire plant succession immediately after disturbance. The majority of the conclusions suggest that there is still much to be learned about how the conditions following a fire are reflected in the interactions between species in the early stages after a fire, and what impact they may have on later successional development.

Plants respond in two different ways to fire: some species survive fire and then resprout, while others are killed by fire, but germinate from fire-resistant seeds (Oliveira et al., 2015). The survivorship of plants after fire is dependent on their characteristics, the meteorological conditions and other disturbances such as grazing (Robberecht and Defossé, 1995; Peláez et al., 2009).

A previous study has shown that the highest values of diversity, exactly referring the most diverse vegetation in the highest zone, were followed by plots from the transitional zone at medium altitudes (Marković et al., 2015b). As the altitude increased, the diversity of fire non-affected vegetation increased. In the present study this trend was not noticed in the first year after the fire. In contrast, the greatest diversity was recorded at lower altitudes, while on plots at higher altitudes the diversity was lower. These findings are in accordance with the fact that more fertile soils have a stronger response to disturbance than other soils, which has been confirmed in previous investigations (Harrison et al., 2003; Grime, 2006). Limestone plots at lower altitudes have a deeper layer of soil than plots at higher altitudes. Short-term patterns of post-fire succession in the vegetation investigated were also dependent on exposure and slope, but to a much lesser extent in comparison to altitude.

The effects of the fire on plant communities were weaker in rockier habitats at higher altitudes where the fire moved faster and therefore lost its severity, giving a better chance to some of the plant forms to resist or to their seeds to survive in the sheltered places between the larger rocks of the fire impacted area.

In the study, the first post-fire year was characterized by moderately low diversity and more important role of annual species, in contrast to the wildfire non-affected vegetation. This was confirmed in a study of fire on limestone grasslands communities in Derbyshire (England) where the representation of short-lived species was higher in the burned plots than in those which were unburned (Lloyd, 1968). In the second year after the fire, a quantitative increase in the species richness and Simpson's index was recorded. The growth of species richness reflects a more intense process of species immigration from the surrounding preserved vegetation toward the burned plots. Hence, during the second year, the diversity of fire affected xeric vegetation on the mountain was improved, being more stable in most cases. The second post-fire year was characterized by an increase in the number of perennial plants. This trend continued in the third year after the fire when bunch grasses and other perennial species became dominant. According to Bennett et al. (2003) and Zedler (2007) grasses usually have capability to recover their full coenological and biological functionality, including reproduction, within one or few years after fire. As some recent studies have shown (Figueira et al., 2016; Wright and Fensham, 2018), the effects of fire on habitats can stimulates the production of inflorescences in some grass species, and hence support their faster spreading. 
The field surveys and observations show that the calcareous grassland vegetation in the study was very sensitive to the fire. Because of the removal of competition in burned areas, the importance of easy spreading plant species with short life cycles generally increased during the first period after the fire. Similar results were found by Ghermandi et al. (2004) and Papanastasis et al. (2002). According to our results the cover values of annual and biennial representatives increased due to the effects of the fire during the first two years. Consequently, the dominant species during the very first stage of vegetation formed after the fire were annual plants (Bromus squarrosus, Filago montana), and they were recorded in most of the plots, reaching high cover values in the overall vegetation. From the same group of plants, the annual (or sometimes biennial) species Sideritis montana was considerably important in the first, and especially second year after the fire, but was almost completely suppressed during the third year. This was plant especially abundant in waste, highly eroded and nutrient-poor, burned surfaces at higher altitudes. Since the cover value of the overall vegetation declines (caused by fire), annual species respond more rapidly and achieve greater cover values than perennial species in the first phase of its restoration. The same results were obtained in limestone Mediterranean mountain ecosystems in Greece (Papanastasis et al., 2002). At the same time, their further existence and cover values are strongly dependent on the degree of perennial species restoration. Namely, several perennial species were less affected by the fast-moving flame, and survived due to the presence of rhizomes, bulbs and similar subterranean organs or semifruticose aboveground sprouts. The production of a high number of new tillers in the early post-fire stages is one characteristic which increased the capability of restoring the perennial grass species (Ghermandi et al., 2004; Gittins et al., 2011; Gonzalez et al., 2015). As expected, sparse members of phanerophytes, as Crataegus monogyna, remained fire non-affected; while some of them (Rosa canina) additionally increased in the later period. Hence, perennial species like Festuca valesiaca, Asperula cynanchica, Euphorbia cyparissias, Galium purpureum, Petrorhagia saxifraga, Teucrium chamaedrys and Satureja kitaibelii were also important in the first stages, as they were minimally damaged by the fire. What's more, the cover values of dense caespitose grasses and semi-shrubs were high and stable all across the post-fire period. Their role in the stabilization of the floristic composition and restoration of the coenological relationships toward the initial communities in the period following the fire could be taken as important, as they were recorded in every season after the fire. Perennials rapidly achieved greater cover values, invading the destroyed habitats from the remnant patches of vegetation sheltered by the rocks, or by dispersion from the fire non-affected vegetation. During the final year of this study, they generally reached high phytocoenological importance, while annual species lost their role in the overall cover. A considerable number of perennials kept their cover values stable in the final two years, while some of them (e.g. Festuca valesiaca, Euphorbia cyparissias, Teucrium chamaedrys, Centaurea stoebe, Sanguisorba minor) increased their coverage. In that way the recovery stage of vegetation formed over the three years after the fire became more similar to the initial vegetation of calcareous grasslands on the mountain, which has been confirmed in other studies (Kucera and Enrenreich, 1962; Kucera and Koelling, 1964). This very quick floristic recovery after fire is also a characteristic of Mediterranean habitats (Caturla et al., 2000; Trabaud, 2003). In a wider sense, the limestone grasslands and rocky ground habitats on Vidlič Mountain have similar ecological characteristics to Mediterranean 
habitats as evidenced by the presence of large number of species with subMediterranean, or even Mediterranean chorological character (Marković et al., 2015b).

In contrast, our results of Sorensen's coefficient of similarity indicate that the floristic composition of the unburned plots is not very similar to the floristic composition of the burned plots. The biggest differences were shown by plots at the highest altitudes, whereby the coefficient of floristic similarity was $20-27 \%$ in the first three years.

Such low floristic similarity can be explained by the geographic distance between the unburned plots and the burned ones. The species composition in grasslands depends much more on the surrounding vegetation than some other habitats such as scrubland (Chust et al., 2006). Community composition was enriched by new fugitive species which increased diversity in a quantitative sense but the floristic composition lost the quality it had before the fire. Similar results were obtained by Mitchell et al. (2009).

\section{Conclusion}

Having in mind species diversity, calcareous grasslands are of great importance for the conservation of biodiversity in Europe. The results for species richness and diversity after large fires in southeastern Serbia confirm that limestone grasses and rocky ground habitats have high resilience to fire. The trend was noticed that species richness and diversity are higher on lower altitudes. On the other hand, the result of Sorensen's coefficient of similarity indicates that the floristic composition of limestone grasses and rocky ground vegetation was changed and showed slow recovery in the stage after burning. The analyses of life form dynamics showed that the percent of annual plants rapidly increased in the first stage of revitalization. In the second and further stages the proportion of therophytes gradually decreased compared to hemicryptophytes. Additional studies in the future should be carried out on the changes in community composition.

Dry grasslands and other types of vegetation formed on limestone, rocky ground areas in Serbia and Balkan Peninsula are important habitats for endemic and some medicinal, especially aromatic plants. Therefore, results on the impact of uncontrolled wildfire on xeric vegetation on limestone terrains would have general application in wildfire management, as well as in nature conservation.

Acknowledgements. This work was supported by the Ministry of Education, Science and Technological Development of the Republic of Serbia [grant numbers: 171025, 173029, 173030, 31070, 172051].

\section{REFERENCES}

[1] Alard, D., Chabrerie B, O., Dutoitc, T., Roched, P., Langlois, E. (2005): Patterns of secondary succession in calcareous grasslands: can we distinguish the influence of former land uses from present vegetation data? - Basic and Applied Ecology 6: 161-173. DOI: 10.1016/j.baae.2005.01.010.

[2] Aleksić, P., Krstić, M., Jančić, G. (2009): Forest fires - ecological and economic problem in Serbia. - Botanica Serbica 33: 167-176.

[3] Anđelković, J., Krstić, B., Bogdanović, P., Jadranić, D., Milenković, P., Milošaković, R., Urošević, D., Dimitrijević, M., Dolić, D., Rakić, O., Jovanović, Lj., Maslarević, Lj., Marković, B., Divljan, M., Đorđević, M. (1977): Osnovna geološka karta, tumač za 
listove Pirot K34-34 i K34-46 Breznik. [Interpretation of the Basic Geological Map, Sheets Pirot K34-34 and K34-46 Breznik]. - Institute for Geological and Geophysical Research, Belgrade, Serbia [in Serbian].

[4] Antonović, G., Mrvić, V. (2008): Zemljišta sliva Nišave. [Soil of the Nišava River Basin]. - Institute of Soil Science, Belgrade, Serbia [in Serbian].

[5] Bennett, A. M., Judd, S. T., Adams, A. M. (2003): Growth and nutrient content of perennial grasslands following burning in semi-arid, sub-tropical Australia. - Plant Ecology 164: 185-199. DOI: https://doi.org/10.1023/A:1021253600712.

[6] Braun-Blanquet, J. (1964): Pflanzensoziologie, Grundzüge der Vegetationskunde. [Plant Sociology, Basic Principles of Vegetation Science]. Third edition. - Spiringer Verlag, Berlin, Wien, New York, USA [in German].

[7] Caturla, R. N., Ranentós, J., Guàrdia, R., Vallejo, R. V. (2000): Early post fire regeneration dynamics of Brachypodium retusum (Pers.) Beauv. in old fields of the Valencia region (eastern Spain). - Acta Oecologica 21: 1-12. DOI: 10.1016/S1146609X(00)00114-4.

[8] Chust, G., Pérez-Haase, A., Chave, J., Pretus, J. L. (2006): Floristic patterns and plant traits of Mediterranean communities in fragmented habitats. - Journal of Biogeography 33: 1235-1245. DOI: 10.1111/j.1365-2699.2006.01492.x.

[9] Čolić, D. (1960): Pionirske vrste i sukcesija biljnih zajednica. [Pioneer Species and Succession of Plant Communities]. - Proceedings of the Biological Institute of NR Serbia 4: 2. Belgrade [in Serbian].

[10] Čolić, D. (1966): Požar kao ekološki faktor u sukcesiji zajednica Pančićeve omorike i redukovanju njenog areala. [Fire as an Ecological Factor in the Succession of Pančić's Omorica Communities and the Reduction of its Area]. - Conservation of Nature, 33. Institute for Nature Conservation of Republic Serbia, Belgrade, Serbia [in Serbian].

[11] Danon, J. (1960): Fitocenološka ispitivanja livada tipa Agrostidetum vulgaris PoterietoFestucetum vallesiacae u okolini Krivog vira [Phytocoenological tests of meadow type Agrostidetum vulgaris Poterieto-Festucetum vallesiacae around Krivi Vir]. - Archives of Biological Sciences 12: 1-2 [in Serbian].

[12] Diklić, N. (1962): Prilog poznavanju šumskih i livadskih fitocenoza Ozrena, Device i Leskovika kod Sokobanje. [Contribution to the knowledge of forest and meadow phycetoneses of Ozren, Devica and Leskovik near Sokobanja] - Journal of Natural History Museum 18: 49-81 [in Serbian].

[13] Diklić, N., Nikolić, V. (1964): O nekim zajednicama pašnjaka i livada na Svrljiškim planinama. [On some communities of pastures and meadows on Svrljiške planine Mountain] - Journal of the Natural History Museum 19: 65-88 [in Serbian].

[14] Dimitrov, T. (1999): Šumski požari u Hrvatskoj, povod za razmišljanje. [Forest fires in Croatia - A motiv for considerations]. - Forestry Journal 9-10(CXXIII): 461-468.

[15] Dinić, A., Stojšić, V., Pavlović, P., Đurđević, L., Mitrović, M., Olđa, M., Vukadinović, B. (2003): Succession of vegetation on the burned area in Deliblato sands. - Third International Balkan Botanical Congress, Sarajevo 18-24 May 2003. Abstracts.

[16] Figueira, J. E. C., Ribeiro, T. K., Ribeiro, C. M., Jacobi, M. C., França, H., Neves, C. O. A., Conceiçäo, A. A., Mouräo, A. F., Souza, M. J. (2016): Fire in Rupestrian Grasslands: Plant Response and Management. - In: Fernandes, G. (ed.) Ecology and Conservation of Mountaintop Grasslands in Brazil. Springer, Cham, pp. 415-448. https://doi.org/10.1007/978-3-319-29808-5_18.

[17] Ghermandi, L., Guthmann, N., Bran, D. (2004): Early post-fire succession in northwestern Patagonia grasslands. - Journal of Vegetation Science 15: 6-76. DOI: 10.1111/j.1654-1103.2004.tb02238.x.

[18] Gittins, C., Ghermandi, L., Bran, D. (2011): Studying the post-fire performance of tussock grasses in Patagonia: survival, biomass production and early competition. Journal of Arid Environments 75: 986-990. DOI: 10.1016/j.jaridenv.2011.05.005. 
[19] Gonzalez, S. L., Ghermandi, L., Peláez, D. V. (2015): Fire temperature effects on perennial grasses from northwestern Patagonian grasslands. - Ecological Research 30: 67-74. DOI: $10.1007 / \mathrm{s} 11284-014-1210-x$.

[20] Grime, J. P. (2006): Plant strategies, Vegetation Processes, and Ecosystem Properties, Second Edition - John Wiley and Sons, London, UK.

[21] Harrison, S., Inouye, D. B., Safford. D. H. (2003): Ecological heterogeneity in the effects of grazing and fire on grassland diversity. - Conservation Biology 17: 837-845. DOI: 10.1046/j.1523-1739.2003.01633.x.

[22] Hijmans, R. J., Guarano, L., Jarvis, A., O’Brien, R., Mathur, P. (2005): DIVA-GIS version 5.4.0.1. - http://www.diva-gis.org/.

[23] Janković, M. (2003): Neke pojave degradacije flore i vegetacije, Metohijske Prokletije. [Some Phenomena of Degradation of Flora and Vegetation, Metohijske Prokletije Mountains] - In: Amidžić, L., Janković, M. M., Jakšić, P. (eds.) Prokletije of Metohia. Natural and Cultural Heritage. Office for Nature Conservation of Serbia, Belgrade, Serbia, pp. 221-230 [in Serbian].

[24] Josifović, M. (ed.) (1970-1977): Flora SR Srbije I-X. [Flora of SR Serbia I-X]. - Serbian Academy of Sciences and Arts, Belgrade, Serbia [in Serbian].

[25] Jovanović-Dunjić, R. (1955): Types of Pastures and Meadows on Suva Planina Mountain. - In: Stanković, S. (ed.) Proceedings of the Institute of Ecology and Biogeography 6(2). Serbian Academy of Science, Belgrade, Serbia, pp. 3-104 [in Serbian].

[26] Jovanović-Dunjić, R. (1956): Types of Pastures and Meadows on Rtanj Mountain. - In: Stanković, S. (ed.) Proceedings of the Institute of Ecology and Biogeography 6(1). Serbian Academy of Science, Belgrade, Serbia, pp. 3-45 [in Serbian].

[27] Jurjević, P., Vuletić, D., Gračan, J., Seletković, D. (2007): Šumski požari u Republici Hrvatskoj (1992-2007). [Forest fires in Republic Croatia (1992-2007)]. - Forestry Journal 1-2: 63-72 [in Croatian].

[28] Karadžić, B., Šošo-Jovanović, V. Z., Jovanović, Popović, R. (1998): "Flora” a Database and Software for Floristic and Vegetation Analysis. - In: Tsekos, I., Moustakas, M. (eds.) Progress in Botanical Research. Kluwer Academic Press, Dodrecht, pp. 69-72.

[29] Kucera, C. L., Ehreinreich, J. H. (1962): Some aspects of burning on Central Missouri prairie. - Ecology 43: 334-336.

[30] Kucera, C. L., Koelling, M. (1964): The influence of fire on composition of Central Missouri Prairie. - The American Midland Naturalist 72: 142-147. DOI: $10.2307 / 2423217$.

[31] Lloyd, S. P. (1968): Effects of fire on a Derbyshire grassland community. - Ecology 53: 915-920. DOI: 10.2307/1934308.

[32] Lukić, T., Marić, P., Hrnjak, I., Gavrilov, M. B., Mladjan, D., Zorn, M., Komac, B., Milošević, Z., Marković, S. B., Sakulski, D., Jordaan, A., Djordjević, J., Pavić, D., Stojsavljević, R. (2017): Forest fire analysis and classification based on a Serbia case study. - Acta Geographica Slovenica 57: 51-63. DOI: 10.3986/AGS.918.

[33] Margaletić, J., Margaletić, M. (2003): Požari u šumi i na šumskom zemljištu kao čimbenici degradacije staništa. [Wildfires in forests and forestry land as factors of the degradation of habitats]. - Forestry Journal 9-10: 475-482 [in Croatian].

[34] Marković, M, Pavlović-Muratspahić, D., Matović, M., Markovic, A., Stankov-Jovanović, V. (2009): Aromatic flora of the Vidlič Mountain. - Biotechnology and Biotechnological Equipment 23: 1225-1229. DOI: 10.1080/13102818.2009.10817643.

[35] Marković, M, Matović, M., Pavlović, D., Zlatković, B., Marković, A., Jotić, B., StankovJovanović, V. (2010): Resources of medicinal plants and herbs collector's calendar of Pirot County (Serbia). - Biologica Nyssana 1(1-2): 9-21.

[36] Marković, S. M., Stankov Jovanović, V., Mitić, V., Stamenković, S., Ilić, M., Pešić, D. (2015a): Study of oak forests and scrubs of hornbeam vegetation, metals content of Teucrium chamaedrys and soils the first year after wildfire on Vidlič Mountain. - Safety Engineering 5(2): 61-68. DOI: 10.7562/SE2015.5.02.0. 
[37] Marković, M., Nikolić, B., Rakonjac, L., Pešić, D. (2015b): Vegetacijske odlike suvih pašnjaka i kamenjara planine Vidlič (Jugoistočna Srbija). [Vegetation patterns of dry grasslands and rocky grounds on Vidlič Mountain (Southeastern Serbia)] - Bulletin of the Faculty of Forestry, University of Belgrade 112: 59-82. DOI: 10.2298/GSF1512059M.

[38] Marković, M, Rakonjac, L., Lučić, A. (2016): Hrastove šume i šibljak grabića druge godine posle požara na planini Vidlič. [Oak forests and scrubs of hornbeam the second year after fire on Vidlić Mountain]. - Pirotski Zbornik 41: 57-71. DOI: 10.5937/pirotzbor1641057M [in Serbian].

[39] Miljković, N. S. (1996): Osnovi pedologije. [Basics of Pedology]. - Institute of Geography, Faculty of Sciences in Novi Sad, Novi Sad, Serbia [in Serbian].

[40] Ministry of Environment and Spatial Planing, Republic of Serbia (2008): Izveštaj o požarima u zaštićenim resursima za 2007. godinu. - Report on Fires in Protected Resources for 2007 [in Serbian].

[41] Mišić, V., Jovanović-Dunjić, R., Popović, M., Borisavljević, L., Antić, M., Danon, A., Blaženčić, Ž. (1978): Ass. Quercetum frainetto-cerris serbicum Rudski 1949. - In: Belić, J. (ed.) Biljne zajednice i staništa Stare planine. [Plant Communities and Habitats of Stara Planina Mountains]. Serbian Academy of Sciences and Arts, Belgrade, Serbia [in Serbian].

[42] Mitchell, R. J., Simonson, W., Flegg, A. L., Santos, P., Hall, J. (2009): A comparison of the resilience of four habitats to fire, and the implications of changes in community composition for conservation: a case study from the Serra de Monchique, Portugal. Plant Ecology and Diversity 2: 45-56. DOI: 10.1080/17550870902752421.

[43] Mueller-Dombois, D., Ellenberg, H. (1974): Aims and Methods of Vegetation Ecology. John Wiley and Sons, New York, USA.

[44] Nikolov, N. (2015): Forest Fires Country Study, Republic of Serbia. - In: Nemeth, A. (ed.) Regional Environmental Center for Central and Eastern Europe, Serbia.

[45] Oliveira, L. J. S., Campagnolo, L. M., Price, E. O., Edwards, C. A., Russel-Smith, J., Pereira, C. M. J. (2015): Ecological implication of fine-scale fire patchiness and severity in tropical savannas of Northern Australia. - Fire Ecology 11(1): 10-31. DOI: 10.4996/fireecology.1101010.

[46] Panić, M. (2007): Program sanacije i obnavljanja požarišta. [The program of rehabilitation and restoration of postfire areas]. - No. 09-3405, Date: 06.08.2007. "Serbia Forests", Pirot, Serbia [in Serbian].

[47] Papanastasis, P. V., Kyriakakis, S., Kazakis, G. (2002): Plant diversity in relation to overgrazing and burning in mountain Mediterranean ecosystems. - Journal of Mediterraneaen Ecology 3: 53-63.

[48] Pausas, G. J., Ribeiro, E. (2017): Fire and plant diversity at the global scale. - Global Ecology and Biogeography 26: 889-897. DOI: 10.1111/geb.12596.

[49] Peláez, D. V., Bóo, R. M., Mayor, D. M., Elía, O. R., Martínez, S. A. (2009): Effect of post/fire defoliation on growth of two native grasses in the Caldenal, Argentina. Phyton: Journal of Experimental Botany 78: 4-11.

[50] Petrović, J. (1999): Priroda Pirotske kotline i gornjeg Ponišavlja. [Nature of the Pirot Structural Basin and Upper Ponišavlje]. - Institute of Geography, Faculty of Sciences in Novi Sad, Novi Sad, Serbia [in Serbian].

[51] Robberecht, R., Defossé, G. E. (1995): The relative sensitivity of two bunchgrass species to fire. - International Journal of Wildland Fire 5: 127-134. DOI: 10.1071/WF9950127.

[52] Rutherford, C. M., Powrie, W. L., Husted, B. L., Turner, C. R. (2011): Early post-fire plant succession in Peninsula Sandstone Fynbos: The first three years after disturbance. South African Journal of Botany 77(3): 665-674. DOI: 10.1016/j.sajb.2011.02.002.

[53] Safford, D. Harrison, S. (2004): Fire effect on plant diversity in serpentinite vs. sandstone chaparral. - Ecology 85(2): 539-548. DOI: 10.1890/03-0039.

[54] Schrautzer, J., Jansen, D., Breuer, M., Nelle, O. (2009): Succession and management of calcareous dry grasslands in the Northern Franconian Jura. Germany. - Tuexenia 29: 339351. 
[55] Smith, N. D., Killeen, J. T. (1995): A comparison of the structure and comparison of montane and lowland tropical forest in the Serriana Pilón Lajas, Beni, Bolivia. Forest biodiversity in north, central and south America, and the Caribbean. - Man and the Biosphere Series 21: 681-700.

[56] Stevanović, V. (1992): Klasifikacija životnih formi biljaka u flori Srbije [Classification of Life Forms of Plants in the Flora of Serbia] - In: Sarić, R. M. (ed.) Flora Srbije 1 [Flora of Serbia 1], Second edition. Srpska Akademija nauka i umetnosti, Beograd, pp: $37-49$ [in Serbian].

[57] Tabaković-Tošić, M, Marković, M., Rajkočić, S., Veselinović, M. (2009): Wildfires in Serbia-Chance or frequent phenomenon. - Sustainable Forestry, Institute of Forestry, Belgrade (Serbia), Collection 59-60: 97-125.

[58] Trabaud, L. (2003): Towards a sounder fire ecology. - Frontiers in Ecology and the Environment 1: 274-275. DOI: 10.1890/1540-9295(2003)001[0274:TASFE]2.0.CO;2.

[59] Türkmen, N., Düzenli, A. (2011): Early post-fire changes in Pinus brutia forests (Amanos Mountains, Turkey). - Acta Botanica Croatica 70: 9-21. DOI: 10.2478/v10184010-0013-6.

[60] Tutin, T. G., Heywood, W. H., Burges, N. A., Moore, D. M., Valentine, H., Walters, S. M., Webb, D. A. (eds.) (1964-1980): Flora Europaea I-V. - Cambrige University Press, London, UK.

[61] Tutin, T. G., Burges, N. A., Chater, O. A., Edmondson, J. R., Heywood, W. H., Moore, D. M., Valentine, D. H., Walters, S. M. Webb, D. A. (eds.) (1993): Flora Europaea 1. Second edition. - Cambrige University Press, London, UK.

[62] Van der Maarel, E. (1966): Over vegetatiestructuren, - relaties en - systemen, in het bijzonder in de duingraslanden van Voorne. (With summary). - Thesis, Univ. Utrecht.

[63] Velchev, V., (ed.) (1982-1989): Flora na NR Bъlgariя I-X. [Flora of RN Bulgaria I-X]. BAN, Sofia, Bulgaria [in Bulgarian].

[64] Vidanović, G. (1955): Visok, Economic Geographyc Exploration. - In: Jovanović, P. (ed.) Special edition of the Geographical Institute Vol 6, Serbian Academy of Science, Belgrade, Serbia [in Serbian].

[65] Vidanović, G. (1960): Vidlič-Zabrđe, Contribute of Recognition Economic Type of Develop and Disposition of Production and Trade of Farms Stagnant Boundary Limestone Area. - In: Vujević, P. (ed.) Special Edition of the Geographical Institute No 15, Serbian Academy of Science, Belgrade, Serbia [in Serbian].

[66] Vukelić, J., Rauš, Đ. (1998): Šumarska fitocenologija i šumske zajednice u Hrvatskoj. [Forest Phytocoenology and Forest Communities in Croatia]. - Faculty of Forestry, University of Zagreb, Zagreb [in Croatian].

[67] Vukićević, E. (1965): Sukcesija vegetacije i prirodno obnavljanje šuma na šumskim požarištima u Srbiji. [Succession of Vegetation and Natural Regeneration of Forests in Serbia]. - Dissertation, Faculty of Forestry, University of Belgrade (Serbia) [in Serbian].

[68] Westhoff, V., Van der Maarel, E. (1973): The Braun-Blanquet Approach. - In: Whittaker, R. H. (ed.) Classification and Ordination of Communities. Handbook of Vegetation Science 5. Junk, The Hague, Netherlands, pp. 617-726.

[69] Whitaker, H. R. (1972): Evolution and measurement of species diversity. - Taxon 21: 213251.

[70] Wright, R. B., Fensham, J. R. (2018): Fire timing in relation to masting: an important determinant of post-fire recruitment success for the obligate-seeding arid zone soft spinifex (Triodia pungens). - Annals of Botany 121(1): 119-128. https://doi.org/10.1093/aob/mcx136.

[71] Zedler, H. P. (2007): Fire Effects on Grasslands. - In: Johnson, A. E., Miyanishi, K. (eds.) Plant Disturbance Ecology: The Process and the Response. Academic Press, San Diego. 